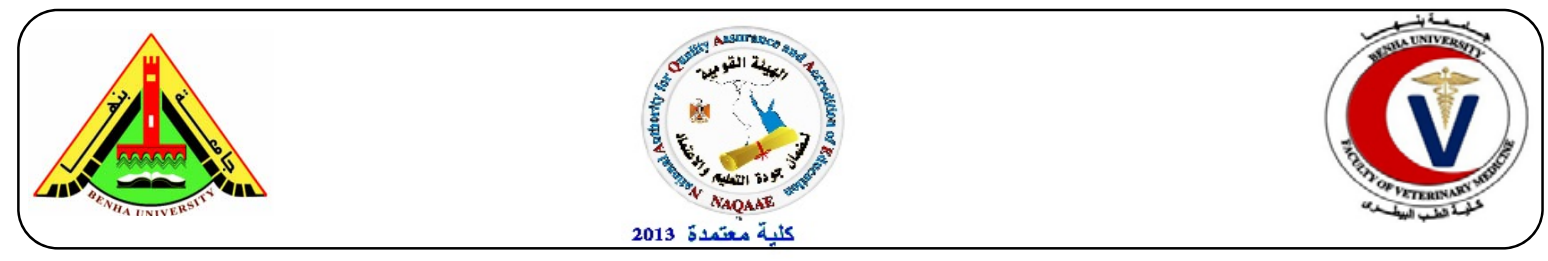

\title{
Antifungal Effect of Some Chemical Preservatives on Aspergillus Niger in Minced Beef Meat
}

\author{
Amani, M. Salem ${ }^{1}$, Reham, A. Amin ${ }^{1}$, Dalia, F. Khater ${ }^{2}$, Loaloa, A. Shokr ${ }^{3}$ \\ ${ }^{1}$ Food Control Dept., Fac. Vet. Med., Benha Univ. ${ }^{2}$ Food Hygiene, Animal Health Research Institute, \\ Tanta Branch. ${ }^{3}$ Food Hygiene, Animal Health Research Institute, Kafr El-Sheikh Branch
}

\section{A B S T R A C T}

A grand total of $1400 \mathrm{~g}$ fresh minced beef meat samples were divided into 7 equal groups $(200 \mathrm{~g}$ of each) and then irradiated. Aspergillus niger was inoculated into each group with infective dose 105 $\mathrm{cfu} / \mathrm{g}$. The used chemical preservatives natamycin $(100,200$ and $300 \mathrm{ppm})$ and potassium sorbate $(0.1 \%$, $0.2 \%$ and $0.3 \%$ ) were added. The inoculated samples were stored at $4 \mathrm{oC}$ in refrigerator till be used. The inoculated groups were examined every $24 \mathrm{hrs}$ for A. niger count and sensory examination (overall acceptability). The experiment was performed in triplicate. Natamycin $(100,200$ and $300 \mathrm{ppm})$ decreased count of $A$. niger ( $\log \mathrm{cfu} / \mathrm{g}$ ) from 5.00 (initial load) to 2.83, 2.79 and 2.76 with reduction percentages $43.40 \%, 44.20 \%$ and $44.80 \%$ on 8 th, 8 th and 10 th days of storage, respectively. Potassium sorbate $(0.1 \%, 0.2 \%$ and $0.3 \%)$ decreased count of $A$. niger $(\log \mathrm{cfu} / \mathrm{g}$ ) from 5.00 (initial load) to 3.02, 2.97 and 2.85 with reduction percentages $39.60 \%, 40.60 \%$ and $43.00 \%$ on 8 th, 8 th and 10 th day of storage, respectively. While, in control group A.niger count increased From 5.00 (initial load) to 5.56 on 6th day Furthermore, natamycin $(300 \mathrm{ppm})$ treated minced meat samples artificially inoculated with A. niger showed overall acceptability till 8th day of storage. In comparison, potassium sorbate $(0.3 \%)$ showed overall acceptability till 7th day. While, control group showed overall acceptability till 4th day. Generally, natamycin $(300 \mathrm{ppm})$ proved to be more efficient than potassium sorbate $(0.3 \%)$ in suppression of $A$. niger growth in minced meat. So, the use of natamycin $(300 \mathrm{ppm})$, as it is safe antifungal agent, is therefore recommended to improve safety of the meat products.

Keywords: Aspergillus niger, antifungal effect, meat products, food preservative.

(BVMJ-30(1): 295-301, 2016)

\section{INTRODUCTION}

$\mathrm{M}$ eat and meat products are considered as good source of high biological value proteins, vitamins. Especially vitamin B and certain minerals specially iron which are essential for growth and health of human beings (Soliman - Salwa, 1999). Fungi comprise a large group of microorganisms which are uniquitos in nature. They can contaminate meat products due to lake of hygienic measures during processing and through using of contaminated additives and spices (Abd El-Rahman, 1987). Aspergillus niger is known to produce several highly specific secondary metabolites, including mycotoxins, which are small organic molecules produced by Filamentous fungi that can cause disease and death in humans and animals through natural exposure route (Bennett, 1987). Aspergillomas or fungal ball caused by $A$. niger are vegetative masses than can form in a host. In humans, aspergillomas are predominant finding in lungs (Ma et al., 2011), but also can be formed in other body cavities such as sinuses, brain and heart (Anandaraja et al., 2006). Hence, the prevention of Aspergillus niger to gain access to meat is absolutely necessary. Natamycin and potassium sorbate are antifungal substances approved 
by FDA for use on the surface of some food items to inhibit the mould spoilage (Griffin, 1994 and Eldaly, 2000). Natamycin is white odorless and tasteless powder which has no influence on the organoleptic properties of the food article (KhoudoKormoff, 2004). Natamycin is a natural antifungal agent produced during the fermentation of bacterium Streptomyces natalensis. It is effective in very low levels and affects the growth of nearly all moulds and yeasts, it also slows down their growth for up to six months, but it cannot completely inhibit it (Zeuthen and Sorensen, 2003). Potassium sorbate one of the most effective food preservatives in controlling mould growth, it is legally used as preservative in numerous processed foods owing to its system of conjugated double bonds (Ferrand et al., 2000). Potassium sorbate is used to improve microbial quality of the meat and increase its shelf-life. It did not cause any adverse effect on the quality characteristics of the meat (Hussein et al., 2012). Sensory evaluation of meat is a good indicator to evaluate the quality of meat and to investigate the possibility of extending shelf life of the meat (Hussien et al., 2012). Sensory characteristics still remain the main purchasing and repeated purchasing criteria (Calkins and Hodgen, 2007). Sensory traits are known to be important to the consumer and thus influence their consumption of meat especially beef.

The aim of the current study was planned out to investigate the antifungal effect of natamycin (100, 200 and $300 \mathrm{ppm}$ ) and potassium sorbate $(0.1 \%, 0.2 \%$ and $0.3 \%)$ on $A$. niger artificially inoculated into minced meat.

\section{MATERIAL AND METHODS}

\subsection{Mould strain}

Aspergillus niger strain was obtained from Microbiological Resources Center (Cairo MIRCEN), Faculty of Agriculture, Ain Shams University, then prepared at the recommended infective dose $105 \mathrm{cfu} / \mathrm{ml}$ at
Animal Health Research Institute (AHRI), Dokki as recorded by Sebti et al. (2005).

\subsection{Preservatives used:}

- Natamycin (100, 200 and 300 ppm).

- Potassium sorbate $(0.1 \%, 0.2 \%$ and $0.3 \%$ ) as recorded by Hassan (2004).

\subsection{Experimental application:}

A grand total of $1400 \mathrm{~g}$ fresh minced meat samples were divided into 7 equal groups (200 $\mathrm{g}$ of each) and then irradiated, the irradiation process was carried out at the National Center for Radiation Research and Technology (NCRRT), Nasr City, Cairo, Egypt. A. niger was inoculated into each group with infective dose $105 \mathrm{cfu} / \mathrm{g}$ as recorded by Sebti et al. (2005). The used chemical preservatives were added according to the following order:

- Control +ve: Inoculated with A. niger strain and not treated with preservatives.

- A: Treated with natamycin (100 ppm) + A. niger strain.

- B: Treated with natamycin (200 ppm) + A. niger strain.

- $\mathrm{C}$ : Treated with natamycin (300 ppm) + A. niger strain.

- D: Treated with potassium sorbate $(0.1 \%)+$ A. nigerstrain.

- E: Treated with potassium sorbate $(0$. $2 \%)+A$. niger strain.

- F: Treated with potassium sorbate $(0.3 \%)+$ A. niger strain.

The inoculated samples were stored at $4^{\circ} \mathrm{C}$ in refrigerator till be used. The inoculated groups were examined every $24 \mathrm{hrs}$ for:

- A. niger count according to Samson (1979).

- Sensory examination (overall acceptability) according to Hemin (2013).

The experiment was performed in triplicate.

\subsection{Statistical analysis:}

The obtained results were statistically evaluated by application of analysis of 
variance (ANOVA) test according to Feldman et al., (2003).

\section{RESULTS}

Tables $(1 \& 2)$ and Fig. (1) Illustrated the antifungal effects and reduction percentages of natamycin $(100,200$ and $300 \mathrm{ppm})$ and potassium sorbate $(0.1 \%$, $0.2 \%$ and $0.3 \%$ ) on $A$. niger artificially inoculated into minced meat samples.

Natamycin (100, 200 and 300 ppm) decreased count of $A$. niger $(\log \mathrm{cfu} / \mathrm{g}$ ) from
5.00 (initial load) to $2.83,2.79$ and 2.76 with reduction percentages $43.40 \%$, $44.20 \%$ and $44.80 \%$ on 8 th, 8th and 10 th days of storage, respectively.

Potassium sorbate $(0.1 \%, 0.2 \%$ and $0.3 \%)$ decreased count of $A$. niger $(\log \mathrm{cfu} / \mathrm{g}$ ) from 5.00 (initial load) to $3.02,2.97$ and 2.85 with reduction percentages $39.60 \%$, $40.60 \%$ and $43.00 \%$ on 8 th, 8 th and 10 th day of storage, respectively. While, in control group $A$. niger count increased From 5.00 (initial load) to 5.56 on 6 th day

Table (1): The effects of various concentrations of natamycin and potassium sorbate on counts of Aspergillus niger (log cfu/g) artificially inoculated into minced meat samples.

\begin{tabular}{ccccccc}
\hline Groups & $\begin{array}{c}\text { Natamycin } \\
100 \mathrm{ppm}\end{array}$ & $\begin{array}{c}\text { Natamycin } \\
200 \mathrm{ppm}\end{array}$ & $\begin{array}{c}\text { Natamycin } \\
300 \mathrm{ppm}\end{array}$ & $\begin{array}{c}\text { Potassium } \\
\text { sorbate } 0.1 \%\end{array}$ & $\begin{array}{c}\text { Potassium } \\
\text { sorbate } 0.2 \%\end{array}$ & $\begin{array}{c}\text { Potassium } \\
\text { sorbate } 0.3 \%\end{array}$ \\
\hline $1^{\text {st }}$ day & 1.60 & 3.00 & 10.40 & 1.00 & 1.60 & 3.00 \\
$2^{\text {nd }}$ day & 2.00 & 3.00 & 10.80 & 1.60 & 2.00 & 3.00 \\
$3^{\text {rd }}$ day & 3.20 & 6.80 & 11.80 & 2.00 & 5.40 & 7.60 \\
$4^{\text {th }}$ day & 6.40 & 8.60 & 12.20 & 2.20 & 6.00 & 8.60 \\
$5^{\text {th }}$ day & 6.40 & 10.80 & 14.60 & 3.80 & 8.60 & 12.00 \\
$6^{\text {th }}$ day & 8.60 & 11.40 & 15.20 & 7.40 & 9.80 & 12.20 \\
$7^{\text {th }}$ day & 11.60 & 13.80 & 16.40 & 9.80 & 10.80 & 13.40 \\
$8^{\text {th }}$ day & 43.40 & 44.20 & 18.40 & 39.60 & 40.60 & 16.00 \\
$9^{\text {th }}$ day & Spoiled & Spoiled & 19.00 & Spoiled & Spoiled & 16.60 \\
$10^{\text {th }}$ day & Spoiled & Spoiled & 44.80 & Spoiled & Spoiled & 43.00 \\
\hline
\end{tabular}

Initial load of $A$. niger $=5.00+0.00 \mathrm{log} \mathrm{cfu} / \mathrm{g}$. The values represent mean+SD of three experiments.

Means within a row followed by different letters are significantly different $(P<0.05)$

Table (2): Reduction \% in counts of Aspergillus niger artificially inoculated into minced meat samples treated with different concentrations of natamycin and potassium sorbate.

\begin{tabular}{ccccccc}
\hline Groups & $\begin{array}{c}\text { Natamycin } \\
100 \mathrm{ppm}\end{array}$ & $\begin{array}{c}\text { Natamycin } \\
200 \mathrm{ppm}\end{array}$ & $\begin{array}{c}\text { Natamycin } \\
300 \mathrm{ppm}\end{array}$ & $\begin{array}{c}\text { Potassium } \\
\text { sorbate } 0.1 \%\end{array}$ & $\begin{array}{c}\text { Potassium } \\
\text { sorbate } 0.2 \%\end{array}$ & $\begin{array}{c}\text { Potassium } \\
\text { sorbate } 0.3 \%\end{array}$ \\
\hline $1^{\text {st }}$ day & 1.60 & 3.00 & 10.40 & 1.00 & 1.60 & 3.00 \\
$2^{\text {nd }}$ day & 2.00 & 3.00 & 10.80 & 1.60 & 2.00 & 3.00 \\
$3^{\text {rd }}$ day & 3.20 & 6.80 & 11.80 & 2.00 & 5.40 & 7.60 \\
$4^{\text {th }}$ day & 6.40 & 8.60 & 12.20 & 2.20 & 6.00 & 8.60 \\
$5^{\text {th }}$ day & 6.40 & 10.80 & 14.60 & 3.80 & 8.60 & 12.00 \\
$6^{\text {th }}$ day & 8.60 & 11.40 & 15.20 & 7.40 & 9.80 & 12.20 \\
$7^{\text {th }}$ day & 11.60 & 13.80 & 16.40 & 9.80 & 10.80 & 13.40 \\
$8^{\text {th }}$ day & 43.40 & 44.20 & 18.40 & 39.60 & 40.60 & 16.00 \\
$9^{\text {th }}$ day & Spoiled & Spoiled & 19.00 & Spoiled & Spoiled & 16.60 \\
$10^{\text {th }}$ day & Spoiled & Spoiled & 44.80 & Spoiled & Spoiled & 43.00 \\
\hline
\end{tabular}


Fig. (1): Reduction \% in counts of Aspergillus niger artificially inoculated into minced meat samples treated with different concentrations of natamycin and potassium sorbate.

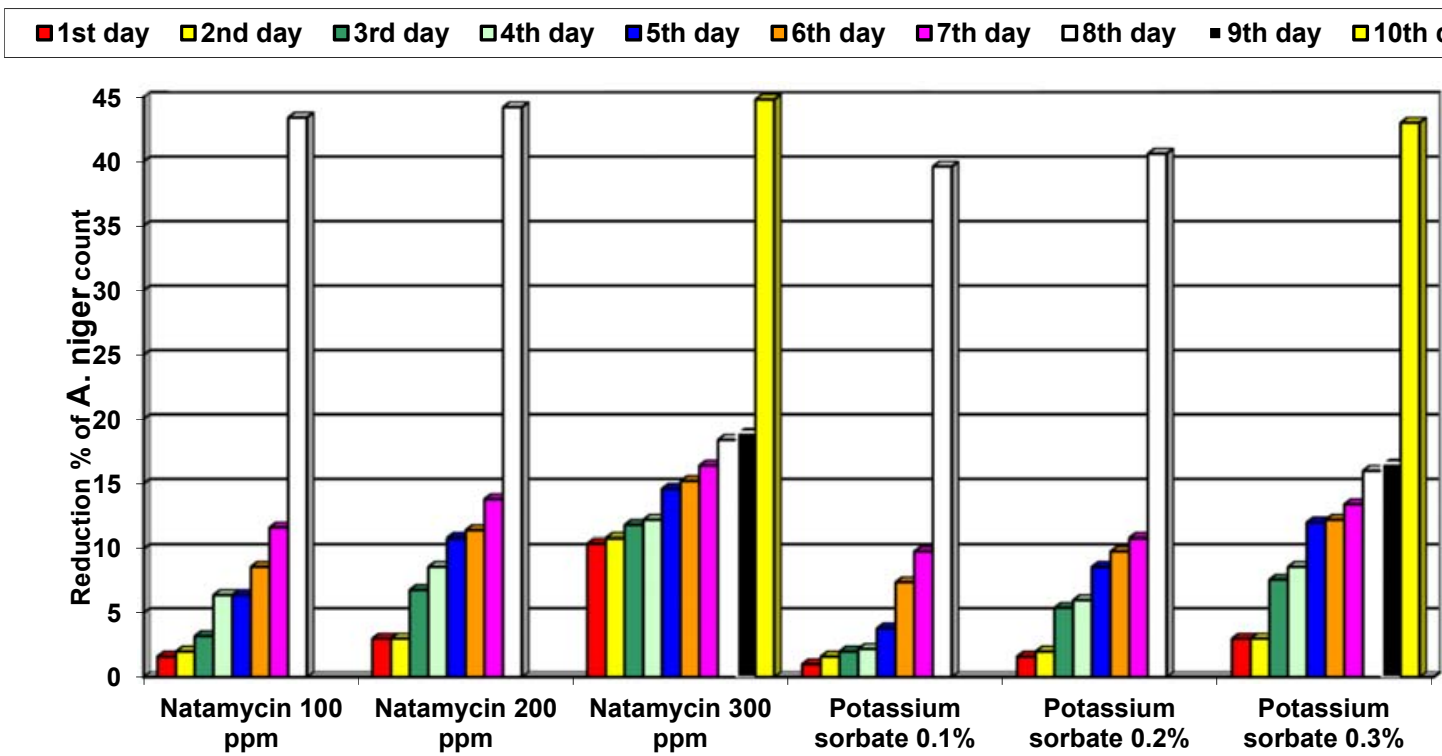

Table (3) illustrated the effects of various concentrations of natamycin and potassium sorbate on overall acceptability of artificially inoculated minced meat samples with Aspergillus niger.

Natamycin (300 ppm) showed overall acceptability extended to 8th day of storage. While, lower concentration (100 and $200 \mathrm{ppm}$ ) showed overall acceptability till 7th day. In comparison, potassium sorbate $\quad(0.3 \%)$ showed overall acceptability extended to 7th day. While, potassium sorbate $(0.1 \%$ and $0.2 \%)$ showed overall acceptability till 6th day. In contrast, the control group showed overall acceptability till 4th day.

Table (3): The effects of various concentrations of natamycin and potassium sorbate on overall acceptability of artificially inoculated minced meat samples with Aspergillus niger

\begin{tabular}{cccccccc}
\hline & \multirow{2}{*}{ Control } & \multicolumn{3}{c}{ Natamycin } & \multicolumn{4}{c}{ Potassium sorbate } \\
& & $100 \mathrm{ppm}$ & $200 \mathrm{ppm}$ & $300 \mathrm{ppm}$ & $0.1 \%$ & $0.2 \%$ & $0.3 \%$ \\
\hline Zero day & 5 & 5 & 5 & 5 & 5 & 5 & 5 \\
$1^{\text {st }}$ day & 4 & 4 & 5 & 5 & 4 & 4 & 5 \\
$2^{\text {nd }}$ day & 4 & 4 & 5 & 5 & 4 & 4 & 4 \\
$3^{\text {rd }}$ day & 3 & 4 & 4 & 4 & 4 & 4 & 4 \\
$4^{\text {th }}$ day & 3 & 3 & 4 & 4 & 3 & 3 & 4 \\
$5^{\text {th }}$ day & 2 & 3 & 3 & 4 & 3 & 3 & 3 \\
$6^{\text {th }}$ day & 2 & 3 & 3 & 3 & 3 & 3 & 3 \\
$7^{\text {th }}$ day & 1 & 2 & 3 & 3 & 2 & 2 & 3 \\
$8^{\text {th }}$ day & 1 & 2 & 2 & 3 & 2 & 2 & 2 \\
$9^{\text {th }}$ day & 1 & 1 & 1 & 2 & 1 & 1 & 2 \\
$10^{\text {th }}$ day & 1 & 1 & 1 & 2 & 1 & 1 & 2 \\
$11^{\text {th }}$ day & 1 & 1 & 1 & 1 & 1 & 1 & 1 \\
\hline $5=$ Very acceptable, $4=$ Acceptable, $3=$ Middle, $2=$ Unacceptable, $1=$ Rejected (Hemin, 2013$)$
\end{tabular}




\section{DISCUSSION}

Mould contamination of some meat products indicated improper sanitary conditions during handling, processing and storage. Also, the adding of bad or inferior quality flavoring agents may increase the load of mould contamination for such products (Gourama and Bullerman, 1995). Hence, the prevention of moulds to gain access the meat is absolutely necessary. Natamycin and potassium sorbate are antifungal substances approved by FDA (Griffin, 1994).

Table (1 \& 2) and Fig. (1) revealed that natamycin $(300 \mathrm{ppm})$ had a higher antifungal effect than that obtained by $(100$ and $200 \mathrm{ppm})$. Furthermore, the high concentration of potassium sorbate $(0.3 \%)$ had a higher inhibitory effect than that obtained by lower concentrations $(0.1 \%$ and $0.2 \%$ ).

The results of the present study agreed with those obtained by Hassan (2004) who examined ninety swabs from the surface of control, potassium sorbate and natamycin sprayed sheep carcasses (30 of each) and mentioned the incidence of total mould count $(\log \mathrm{cfu} / \mathrm{g})$ decreased from 4.75 in control group to 3.45 and 2.81 in potassium sorbate and natamycin treated groups, respectively. Furthermore, the incidence of Aspergillus species reduced from (56.67\%) in control group to $(30 \%)$ and $(13.33 \%)$ in both potassium sorbate and natamycin treated groups, respectively. In addition, he reported that the incidence of $A$. niger reduced from $(6.67 \%)$ in control group to $(3.33 \%)$ in both potassium sorbate and natamycin treated groups and also agreed with those obtained by Hafez (2005) who examined thirty samples of minced beef and reported that potassium sorbate $(2.5 \%)$ reduced the total mould count $(\log \mathrm{cfu} / \mathrm{g})$ from 3.00 (minimum) and 4.30 (maximum) to 2.30 (minimum) and 3.60 (maximum). Furthermore, he mentioned that potassium sorbate $(2.5 \%)$ reduced A. niger incidence from $33(18.96 \%)$ to $9(16.66 \%)$. Also, these findings agreed with Hassan and ElLawandy (2006) who found that natamycin $(50 \mathrm{ppm})$ reduced the total mould count $(\log \mathrm{cfu} / \mathrm{g})$ from 3.44 in ordinary formulated sausage to 2.28 in natamycin treated sausage and from 3.10 in ordinary formulated frankfurter to 1.96 in natamycin treated frankfurter. In addition, natamycin $(50 \mathrm{ppm})$ reduced the incidence of A. niger from $2(10 \%)$ in ordinary formulated sausage to $1(5 \%)$ in treated one and from 1 $(5 \%)$ in ordinary formulated frankfurter to $0(0 \%)$ in treated one.

These findings also agreed with Peter Pipek et al. (2010) who reported that natamycin $(0.1 \%$ and $0.2 \%)$ proved to be the most efficient in mould suppression on the surface of dry sausage (both heat treated and fermented) in comparison with potassium sorbate $(2 \%)$. Furthermore, these results agreed with Hussein et al. (2012) who examined eighty samples from fresh camel meat and reported that potassium sorbate $(0.3 \%)$ reduced total mould count $(\log \mathrm{cfu} / \mathrm{g})$ from 3.3, 4.5, 5.3 and rejected in untreated samples to $2.9,3.1,3.1$ and 3.1 in treated samples at zero, 3rd, 5th and 7th day, respectively with reduction percent of $98.3 \%$. In addition, these findings agreed with El-Tawab (2014) who reported that natamycin $(0.1 \%)$ had a higher inhibitory effect than potassium sorbate $(2 \%)$ as total mould count $(\log \mathrm{cfu} / \mathrm{g})$ reduced from 4.69 in control group to 2.96 and 3.39 in natamycin and potassium sorbate treated groups, respectively. Furthermore, natamycin completely reduced $\mathrm{A}$. niger count to $(0 \%)$. In comparison, potassium sorbate had lower inhibitory effect on A. niger as it reduced $\mathrm{A}$. niger count to 1 (6.67\%).

Natamycin causes defects in the permeability of membrane of the fungi as natamycin interacts with sterols, which are present in the cellular membrane of the fungal cells and thus it destructs the selective permeable membrane (Jay, 2000). Potassium ions are forced out from the cell, followed by amino acids, when a solution 
of higher concentration of natamycin is used (Robert and Hui, 2001).

Potassium sorbate interferes with the spore germination, inhibits the activity of several enzyme systems and interferes with substrate and electron transport mechanisms and heat-resistance apparatus of the spores (Oloyede and Scholefiedl, 1994 and Davidson et al., 2005).

Moreover, natamycin proved to be more efficient than potassium sorbate in suppression of A. niger because the optimum activity of natamycin lies in the range of $\mathrm{pH} 3-9$, whereas the efficiency of potassium sorbate is limited to $\mathrm{pH}$ range 14 above which its protective power decreases (Beuchat, 1998). Consequently, natamycin is specific antimycotic agent and have no antibacterial activity due to absence of ergosterol-like compound in the bacterial cell membrane. In contrast, potassium sorbate have both antibacterial and antimycotic effects and this may limit its efficiency to control the mould growth, where large amounts of potassium sorbate is consumed to destroy the bacterial cells (Deacon, 1997).

Finally, the present study allowed to conclude that natamycin $(300 \mathrm{ppm})$ proved to be more efficient than potassium sorbate $(0.3 \%)$ in suppression of A. niger growth in minced meat. So, the use of natamycin (300 $\mathrm{ppm})$, as it is safe antifungal agent, is therefore recommended to improve safety of meat products.

\section{REFERENCES}

Abd El-Rahman, H.A. 1987. Mycological studies on some selected spices with special references to aflatoxin producing Aspergillus species.Assiut Vet. Med. J., 19(37): 93-101.

Anandaraja, S., Kothari, S.S., Nath, R. 2006. Fungal ball blocking the aortic valve. Echocardiography, 2: 164.

Bennett, J.W. 1987. Mycotoxins mycotoxicosis, mycotoxicology and
Mycopathologia. Mycopathologia, 100: 3-5.

Beuchat, L.R. 1998. Effects of potassium sorbate and sodium benzoate on inactivating moulds heated in broth containing sodium chloride and sucrose. J. Food Protect. 62(10): 765769.

Calkins, C.R., Hodgen, J.M. 2007. A fresh look at meat flavor. Meat Science, 7(1): 63-80.

Davidson, P.M., Sofos, J.N., Branen, A.L. 2005. Antimicrobials in Food. $3^{\text {rd }}$ Ed., CRC Press, Boca Raton, FL. pp. 1217, 29, 68, 116, 151, 460-469 ISBN: 0-8247-4037-4038.

Deacon, J.A. 1997. Prevention and control of fungal growth. In: Modern mycology (eds. M. Carilile and S. Watkinson), $3^{\text {rd }}$ Ed., Oxford, Blackwell, pp: 289-290.

El-Daly, A.E. 2000. Fundamentals of Meat Hygiene. $1^{\text {st }}$ Ed., Egypt

El-Tawab, M.M. 2014. Studies on mycotoxins in some meat products. M.V.Sc. (Meat Hygiene), Fac. Vet. Med., BenhaUniv.Egypt.

Feldman, D., Hoffman, R., Simpson, J. 2003. The solution for data analysis and presentation graphics. $2^{\text {nd }} \mathrm{Ed}$. Abacus Landcripts, Inc., Barkeley, CA, USA

Ferrand, C., Marc, F., Fritsch, P., Desiant, B.G. 2000. Genotoxicity study of reaction products of sorbic acid. J. Agric. Food. Chem., 48(8): 36053610 .

Gourama, H., Bullerman, L.B. 1995. Aspergillus flavus and Aspergillus parasiticus: Aflatoxigenic fungi of concern in foods and seeds. A Review: J. Food Protect, 58(12): 1495-1404.

Griffin, D. 1994. Fungicides. In: Fungal Physiology, (eds. C. Roberts and F. Rinaldi), $2^{\text {nd }}$ Ed., New York, WileyLiss, Inc., pp. 416-417.

Hafez, A.E., El-Sebaey, E.S. 2005. Role of potassium sorbate as a mould decontaminant in minced meat. Zag. 
Vet. J. (ISSN 1110-1458), 33(1): 9598.

Hassan, M.A. 2004. Control of mycological hazards in sheep carcasses with special reference to aflatoxins. SCVMJ, VII (2): 359-366.

Hassan, M.A.I., Hanan, M.T. El-Lawandy 2006. Control of mycological hazards associated with consumption of some meat products with special reference to mycotoxins. Zag. Vet. J. (ISSN, 1110-1458), 34(1): 12-18.

Hemin, N.M. 2013. Study of some chemical, physical, sensory and bacteriology characteristics of canned Changes possible after use of natamycin. Wein. Wiss. 39: 45-50.

Ma, J.E., Yun, E.Y., Kim, Y.E., Lee, G.D., Cho, Y.J., Jeong, Y.Y., Jeon, K.N., Jang, I.S., Kim, H.C., Lee, J.D. , Hwang, Y.S. 2011. Endobronchial aspergilloma: report of 10 cases and literature review. Yonsei Med. J. 52: 787-792.

Ooleyede, O.B., Scholefield, J. 1994. Inhibition of Bacillus spores by combinations of heat, potassium sorbate, $\mathrm{NaCl}$ and phosphates. World. J. Microbiol. andBiotechnol. 10(5): 579-582.

Petr-Pipek, B.R., Anna, L., Ladislay, S. 2010. Suppression of mould growth on dry sausages. Czech J. Food Sci., 28(4): 258-263. chicken meat imported to Sulaymaniyah markets, Iraq. International Journal of Nutrition and Metabolism, 5(7): 128-133.

Hussein, A.M., El-Ghareeb, W.R., Lotfy, O.O. 2012. Shelf life improvement of camel meat treated with potassium sorbate $0.3 \%$. Journal of American Science, 8(4): 507-511.

Jay, J.M. 2000. Modern Food Microbiology. $5^{\text {th }}$ Ed. D. Van Nostrand Company, New York.

Khoudokormaff, B. 2004. Are resistance development and morphological

Robert, S.I., Hui, Y.H. 2001. Dictionary of food ingredients. $4^{\text {th }}$ Ed. Springer Verlag, New York, pp. 350-354.

Samson, R.A. 1979. A completion of the Aspergilli described since 1965. Studies in Mycology No. 18:1-36.

Sebti, I., Martial-Gros, A., Carnet-Pantiez, A., Grelier, S., Coma, V. 2005. Chitosan polymer as bioactrive coating and film against Aspergillus niger contamination. Journal of Food Science, 70, M100-M104.

Soliman, Salwa, R. 1999. Risk of street food vending on public health. M.V.Sc. Thesis, Fac. Vet. Med., Cairo Univ.

Zeuthen, P., Sorensen, L. 2003. Food Preservation Techniques. Woodhead Publishing, Cambridge, 15-16. 